\title{
Catalytic and antimicrobial properties of $\alpha$-amylase immobilised on the surface of metal oxide nanoparticles
}

\author{
Olga Długosz $^{1} \cdot$ Julia Matysik $^{1} \cdot$ Wiktoria Matyjasik $^{1} \cdot$ Marcin Banach $^{1}$
}

Received: 27 August 2020/Accepted: 20 October 2020/Published online: 1 November 2020

(C) The Author(s) 2020

\begin{abstract}
New methods of obtaining products containing enzymes reduce the costs associated with obtaining them, increase the efficiency of processes and stabilize the created biocatalytic systems. In the study a catalytic system containing the enzyme $\alpha$-amylase immobilized on $\mathrm{ZnO}$ nanoparticle and $\mathrm{Fe}_{3} \mathrm{O}_{4}$ nanoparticles was created. The efficiency of the processes was obtained with variables: concentrations of enzymes, temperatures and times, to define the best conditions for running the process, for which were determined equilibrium and kinetics of adsorption. The most effective parameters of $\alpha$-amylase immobilization on metal oxides were determined, obtaining $100.8 \mathrm{mg} / \mathrm{g}$ sorption capacity for $\mathrm{ZnO}$ and $102.9 \mathrm{mg} / \mathrm{g}$ for $\mathrm{Fe}_{3} \mathrm{O}_{4}$ nanoparticles. Base on the best parameters, $\mathrm{ZnO}-\alpha$-amylase was investigated as an antimicrobial agent and $\mathrm{Fe}_{3} \mathrm{O}_{4}-\alpha-$ amylase was tested as a catalyst in the process of starch hydrolysis. As a result of the conducted experiments, it was found that $\alpha$-amylase immobilized on $\mathrm{Fe}_{3} \mathrm{O}_{4}$ nanoparticles maintained high catalytic activity (the reaction rate constant $\mathrm{K}_{\mathrm{M} \text { - }}$ $=0.7799\left[\mathrm{~g} / \mathrm{dm}^{3}\right]$ and the maximum reaction rate $\left.\mathrm{V}_{\max }=8.660\left[\mathrm{~g} /\left(\mathrm{dm}^{3} \mathrm{~min}\right)\right]\right)$.
\end{abstract}

Keywords $\alpha$-amylase $\cdot$ Metal oxide nanoparticles $\cdot$ Immobilization $\cdot$ Nanobiocatalytic material

\section{Introduction}

Enzymes in industry, especially in biocatalysis, become increasingly popular. Enzymes are macromolecules that act as specific (bio)catalysts, accelerating or enabling chemical reactions by reducing the activation energy of the process $[1,2]$. New methods of enzyme processing are aimed at reducing the costs associated with obtaining them, increasing the efficiency of processes and stabilizing the created biocatalytic systems [3]. Nanotechnological methods are becoming widely used to overcome these problems. The increased surface area of the nanoparticles makes the immobilization of enzymes effective, which ultimately promotes the catalytic activity of proteins $[4,5]$.

An $\alpha$-amylase classified as EC 3.2.1.1 belongs to glycoside hydrolases and acts on glycosidic bonds, exactly on $\alpha-1,4$-glycosidic bonds [6]. The enzyme decomposes starch

Marcin Banach

marcin.banach@pk.edu.pl

1 Faculty of Chemical Engineering and Technology, Institute of Chemistry and Inorganic Technology, Cracow University of Technology, Warszawska St. 24, 31-155 Cracow, Poland to two or three saccharides. In the human body it occurs in saliva and is secreted by the pancreas. The amylase group is used in industries related to fermentation processes or starch decomposition [7, 8].

An immobilisation of enzymes is intended to improve the resistance of biocatalysts to changing reaction conditions that adversely affect the catalytic performance of the free enzyme. The sensitivity of enzymes to changes in process conditions results from their composition and a change in the structure of enzymes may cause their complete inactivation [9]. Immobilization has a positive effect on the structure of the catalytic protein by stabilizing, resulting in increased tolerance to $\mathrm{pH}$, temperature or denaturants. Modification of the protein by connecting it to the carrier facilitates its separation from the reaction mixture after the process. The resulting products are not contaminated with the enzyme and the enzyme deposited on the carrier can be reused. The immobilization of the biocatalyst also extends its catalytic activity so that it can be used repeatedly [10]. However, the immobilisation process may be associated with the deterioration of the catalytic properties of the entire biocatalyst. This is due to the stiffening of the protein structure and the restriction of the 
transport of substrates and products to and from the place of the active enzyme [11].

Enzymes are characterized by additional catalytic functions. In addition to their catalytic functions, some enzymes present additional properties, e.g. antimicrobial. Depending on the future use of the enzymes, as carriers of enzymes $\mathrm{ZnO}, \mathrm{Fe}_{3} \mathrm{O}_{4}, \mathrm{SiO}_{2}, \mathrm{TiO}_{2}, \mathrm{Ag}$ or $\mathrm{Au}$ nanoparticles can be commonly used $[12,13]$. By using enzymes combined with selected nanomaterials that show biocidal activity $(\mathrm{CuO}, \mathrm{ZnO}, \mathrm{Ag}, \mathrm{Cu})$, it is possible to obtain products with synergistic effect $[14,15]$. The antimicrobial properties are distinguished by enzymes from the hydrolysis group (e.g. glycosidase and peptidase) due to the possibility of decomposition of peptidoglycans contained in cell walls, as well as oxidoreductase (e.g. oxidase), which antimicrobial activity is indirect and results from products catalysed by them [16, 17].

The immobilisation by an adsorption on the surface of insoluble carrier is a method often appropriate. The method is based on the formation of bonds between the enzyme and the carrier resulting from hydrogen, hydrophobic, electrostatic, ionic and van der Waals forces [18]. The weak interactions do not influence the tertiary structure of the enzyme, which allows maintaining high catalytic activity. At the other side, the bonds can easily be broken off, so that the protein can be washed away, reducing the activity of the preparation. Through its ease of application of immobilization via adsorption and the low cost of the method, it is a widely used technique. The adsorption enables the use of many types of media that are selected for a sufficiently high protein affinity to the matrix. Depending on the choice of carrier, as well as the enzyme used and the parameters of the process environment, the amount of immobilized enzyme changes [19]. The covalent immobilisation is a method that involves the formation of stable and permanent chemical bonds between the enzyme and the carrier, which limits the leaching of the enzyme from the matrix, extending the activity of the product [20].

The aim of the study was to carry out the process of $\alpha$ amylase immobilization on the surface of metal oxide nanoparticles and to obtain materials with antimicrobial and biocatalytic properties. The scope of the study included the determination of the influence of the parameters of the process of obtaining materials on the efficiency of this process, analysis of equilibrium and kinetic parameters of the process and determination of the activity of $\alpha$-amylase immobilized on $\mathrm{Fe}_{3} \mathrm{O}_{4}$ in the process of hydrolysis of starch and antimicrobial properties of $\alpha$-amylase immobilized on $\mathrm{ZnO}$ nanoparticles. The $\mathrm{Fe}_{3} \mathrm{O}_{4}$ nanoparticles allow to separate the biocatalyst from the reaction system, while $\mathrm{ZnO}$ nanoparticles allow to obtain material with the increased antimicrobial activity.

\section{Materials and methods}

\section{Materials}

Iron(III) chloride $\mathrm{FeCl}_{3} \cdot 6 \mathrm{H}_{2} \mathrm{O}$ (Sigma Aldrich) and iron(II) sulphate $\mathrm{FeSO}_{4} \cdot 7 \mathrm{H}_{2} \mathrm{O}$ (Sigma Aldrich) were used as precursors of iron oxide nanoparticles. Sodium hydroxide ( $\mathrm{NaOH}$ Sigma Aldrich) and sodium carbonate $\left(\mathrm{Na}_{2} \mathrm{CO}_{3}\right.$ (Sigma Aldrich)) were used as a precipitating agent. The enzyme tested was $\alpha$-amylase from Aspergillus oryzae (Sigma Aldrich).

\section{Synthesis of $\mathrm{Fe}_{3} \mathrm{O}_{4}$ and $\mathrm{ZnO}$ nanoparticles}

The solutions of $\mathrm{FeCl}_{3} \cdot 6 \mathrm{H}_{2} \mathrm{O}$ and $\mathrm{FeSO}_{4} \cdot 7 \mathrm{H}_{2} \mathrm{O}$ were added to the Teflon vessel in the molar ratio of iron ions 1:1. In the presence of ultrasounds (Hielscher UP400St sonicator), an aqueous solution of $\mathrm{NaOH}$ acting as a precipitating agent of iron hydroxide was injected and the mixture was homogenised for $3 \mathrm{~min}$. Then, in the MAGNUM II microwave reactor at $180{ }^{\circ} \mathrm{C}$ for $15 \mathrm{~min}$, a dehydration process was carried out to obtain $\mathrm{Fe}_{3} \mathrm{O}_{4}$ nanoparticles. The zinc oxide nanoparticles were obtained in the presence of ultrasound by dropping into a solution of $\mathrm{ZnSO}_{4} \cdot 7 \mathrm{H}_{2} \mathrm{O}$ a solution of $\mathrm{Na}_{2} \mathrm{CO}_{3}$ (for complete precipitation of zinc hydroxide) and after $3 \mathrm{~min}$ the suspension was in the microwave reactor at $180{ }^{\circ} \mathrm{C}$ for $10 \mathrm{~min}$. The materials were filtered, washed and dried at $105{ }^{\circ} \mathrm{C}$ for $24 \mathrm{~h}$. The schematic diagram for the process was presented in Fig. 1.

\section{Preparation of $\alpha$-amylase immobilised on metal oxide nanoparticles}

To the solution of $\alpha$-amylase from Aspergillus oryzae (Sigma Aldrich) with variable initial enzyme concentration $100 \mathrm{mg}$ of $\mathrm{Fe}_{3} \mathrm{O}_{4}$ or $\mathrm{ZnO}$ nanoparticles were added. The process was carried out at $20-30{ }^{\circ} \mathrm{C}$ in the time from 30 to $120 \mathrm{~min}$. At the end of the process, the solution was filtered and the filtrate was examined spectrophotometrically to analyse the enzyme concentration and assess the efficiency of the process. The process efficiency (E) was determined from the equation:

$E=\frac{C_{\text {enzyme }, 0}-C_{\text {enzyme }, t}}{C_{\text {enzyme }, 0}} \cdot 100 \%$

where: $\mathrm{C}_{\text {enzyme, } 0}$-spectrophotometrically measured concentration of the $\alpha$-amylase solution $\left[\mathrm{mg} / \mathrm{dm}^{3}\right], C_{\text {en- }}$ zyme,t - spectrophotometrically measured concentration of the $\alpha$-amylase after sorption process $\left[\mathrm{mg} / \mathrm{dm}^{3}\right]$. The amount of material that was adsorbed in the ratio of the amount of oxide (q) was determined from the equation: 
Fig. 1 Schematic diagram of the process aqueous solution of $\mathrm{Zn}\left(\mathrm{NO}_{3}\right)_{2}$

or

aqueous solution of $\mathrm{NaOH}$ aqueous mixture of $\mathrm{FeCl}_{3}$ and $\mathrm{FeSO}_{4}$
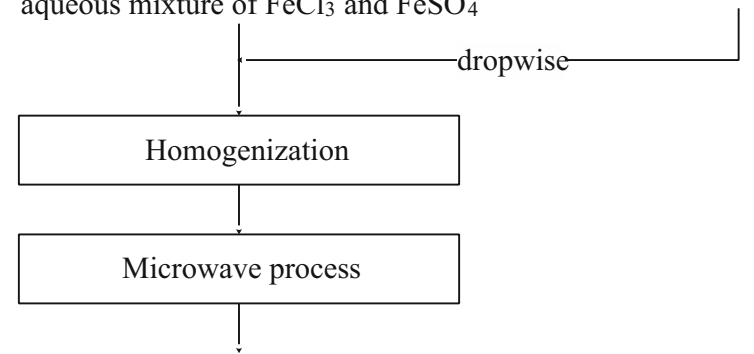

suspension of $\mathrm{ZnO}$ NPs

or

suspension of $\mathrm{Fe}_{3} \mathrm{O}_{4} \mathrm{NPs}$

supernatant

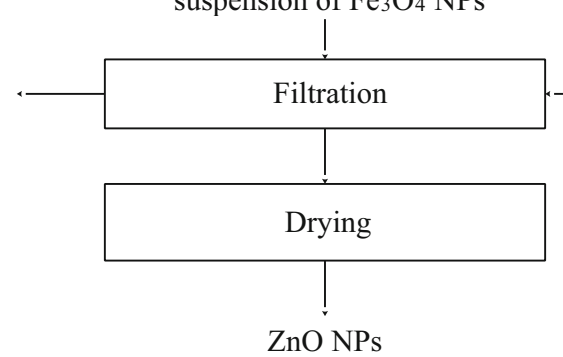

or

$\mathrm{Fe}_{3} \mathrm{O}_{4} \mathrm{NPs}$

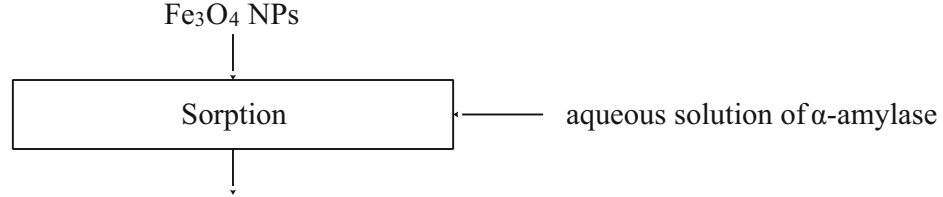

suspension of $\mathrm{ZnO}-\alpha$-amylase

or

suspension of $\mathrm{Fe}_{3} \mathrm{O}_{4}-\alpha$-amylase

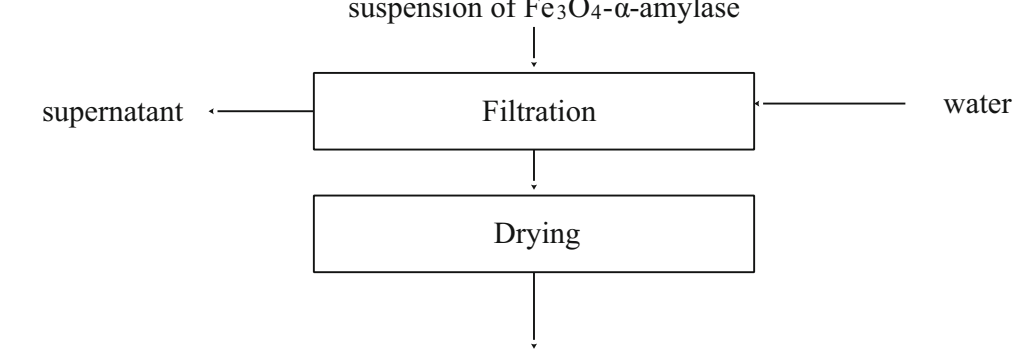

$\mathrm{Fe}_{3} \mathrm{O}_{4}$ - $\alpha$-amylase or $\mathrm{ZnO}-\alpha$-amylase

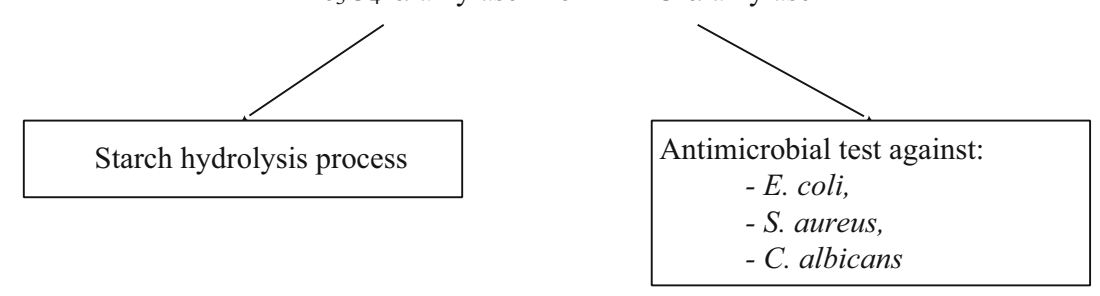

$q=\frac{\left(C_{\text {enzyme }, 0}-C_{\text {enzyme }, t}\right) \cdot V}{m_{M e O_{x}}}\left[\frac{m g}{g}\right]$

Table 1 contains the variables tested in the process of the immobilisation of $\alpha$-amylase on the metal oxides nanoparticles with ranges of variability of input quantities.

On the basis of statistical analysis, the variables and the

where: $\mathrm{m}_{\mathrm{MeOx}}$-mass of metal oxide nanoparticles [mg], $\mathrm{V}$-volume of the enzyme solution. way to which they affected the efficiency of the sorption process were determined. The analysis was carried out using the program STATISTICA 10.0. By determining 
Table 1 Range of variability of input quantities of the $\alpha$ amylase immobilisation process on metal oxide nanoparticles

\begin{tabular}{lllll}
\hline Input variable & Symbol & Unit & Minimum value & Maximum value \\
\hline Temperature & $\mathrm{T}$ & {$\left[{ }^{\circ} \mathrm{C}\right]$} & 20 & 30 \\
Initial enzyme concentration & $\mathrm{C}_{\mathrm{enz}}$ & {$\left[\mathrm{g} / \mathrm{dm}^{3}\right]$} & 0,1 & 1 \\
Sorption time & $\mathrm{t}$ & {$[\mathrm{min}]$} & 30 & 120 \\
\hline
\end{tabular}

these parameters, the most favourable conditions for the immobilisation process were selected. Then, the sorption was carried out at selected parameters in order to obtain the most suitable system of the metal oxide nanoparticles with the enzyme for further research.

\section{Kinetic and equilibrium parameters of the $\alpha$ - amylase immobilisation process}

The equilibrium and the kinetics of the processes were examined. Analogously to the study of immobilization efficiency, $100 \mathrm{mg}$ of the metal oxides were prepared and then $10 \mathrm{~cm}^{3}$ of enzyme solution of proper concentration was added. After the process, the solution was examined spectrophotometrically. The equilibrium parameters and process kinetics were determined using selected models (Table 2).

\section{Material characteristics}

The UV-Vis spectroscopy was used to quantify the $\alpha$ amylase content in the solutions. The determination method was based on modified Lowry's method [23]. The measurement was performed at $670 \mathrm{~nm}$ with the Rayleigh UV-1800 spectrophotometer.

The prepared mixtures: A: $2 \%$ solution of $\mathrm{Na}_{2} \mathrm{CO}_{3}$ in $0.1 \mathrm{M} \mathrm{NaOH}, \mathrm{B}: 1 \%$ solution of $\mathrm{CuSO}_{4}$. C: $2 \%$ sodium tartrate solution, D: $100 \mathrm{~cm}^{3}$ of solution $\mathrm{A}+1 \mathrm{~cm}^{3} \mathrm{~B}+1$ $\mathrm{cm}^{3} \mathrm{C}$, prepared $30 \mathrm{~min}$ before the measurement, E: FolinCiocalteu's solution diluted with distilled water in the ratio

Table 2 Examined equilibrium models and sorption kinetics [21, 22]

Equilibrium models sorption processes

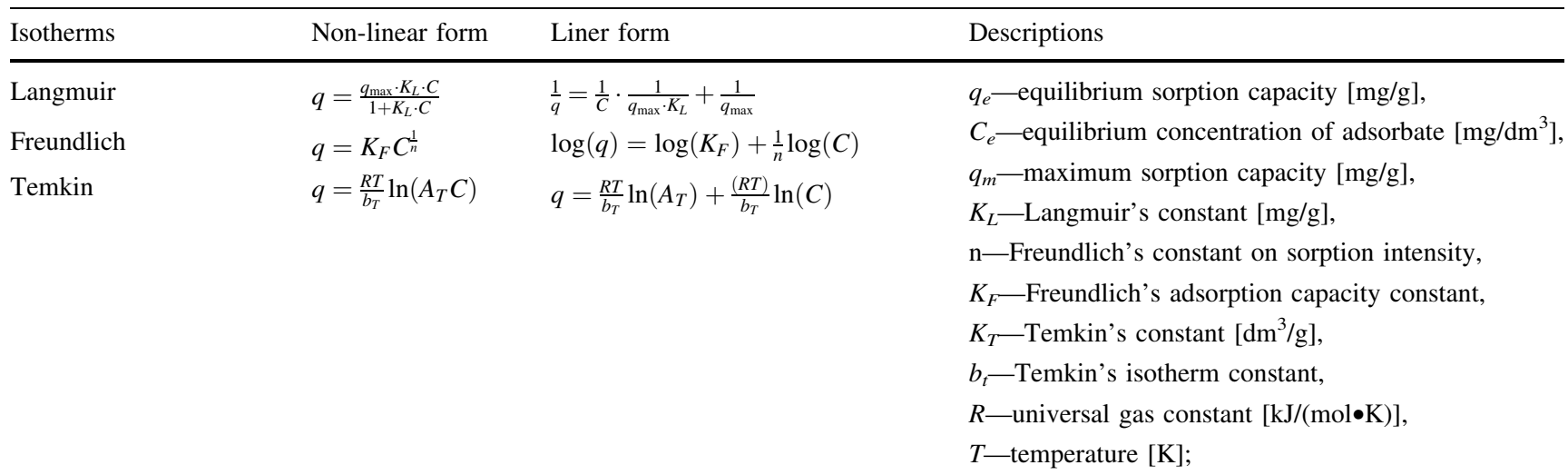

Kinetics models sorption processes

$\begin{array}{lll}\text { Model } & \text { Non-linear form } & \text { Linear form } \\ \text { Pseudo-first order } & \frac{d q_{t}}{d t}=k_{I}\left(q_{\max }-q_{t}\right) & \log \left(q_{\max }-q_{t}\right)=\log \left(q_{\max }\right)-\frac{k_{I}}{2,303} t \\ \text { Pseudo-second order } & \frac{d q_{t}}{d t}=k_{I I}\left(q-q_{t}\right)^{2} & \frac{t}{q_{t}}=\frac{1}{k_{I I} q^{2}}+\frac{1}{q} t \\ \text { Elovich } & \frac{d q_{t}}{d t}=\alpha \exp \left(-\beta q_{t}\right) & q_{t}=\frac{1}{\beta} \ln (\alpha \beta)+\frac{1}{\beta} \ln (t) \\ \text { Intramolecular diffusion } & R=k_{i d}(t)^{a} & \log (R)=\log \left(k_{i d}\right)+\operatorname{alog}(t)\end{array}$

Descriptions

$\mathrm{q}_{\mathrm{t}}$ - sorption capacity after time $\mathrm{t}[\mathrm{mg} / \mathrm{g}]$,

$\mathrm{q}_{\mathrm{e}}$-equilibrium sorption capacity $[\mathrm{mg} / \mathrm{g}]$,

$t$-time [min],

$k_{l}$-pseudo-first order constant $\left[\mathrm{min}^{-1}\right]$,

$k_{2}$-pseudo-second order constant $\left[\frac{\mathrm{gdm}^{3}}{\mathrm{mg} \mathrm{min}}\right]$,

$\alpha$-initial rate of adsorption $\left[\frac{\mathrm{mg}}{\mathrm{gmin}}\right]$,

$\beta$-adsorption constant,

$\mathrm{R}$-share of absorbed particles [\%],

$\mathrm{k}_{\mathrm{id}}$ - constant rate $\left[\mathrm{min}^{-1}\right.$ ],

$\mathrm{a}-$ constant depending on the system 
1:1. The samples for spectrophotometric tests were prepared by adding $1 \mathrm{~cm}^{3}$ of the test solution, $5 \mathrm{~cm}^{3}$ of solution $\mathrm{D}$, after $10 \mathrm{~min} 0.5 \mathrm{~cm}^{3}$ of reagent $\mathrm{E}$ was added and the sample remained in the dark. After $30 \mathrm{~min}$, the absorbance of the samples was measured at $670 \mathrm{~nm}$. The reference curves were made using $\alpha$-amylase.

Studies on crystalline structure of metal oxides were carried out using Philips X'Pert Camera diffractometer with PW 1752/00 $\mathrm{CuK} \alpha$ monochromator in the range of angles $2 \theta$, from 10 to $60^{\circ}$. The size of nanoparticles crystallites based on the metal oxides was determined on the basis of Scherrer's equation:

\section{$d=\frac{K \cdot \lambda}{F W H M \cdot \cos \theta}$}

where: d-average size of crystallites, FWHM-peak width at half of its height, which is proportional to the size of the crystallite, $\mathrm{K}$-Scherrer constant, depending on the shape of the particles (for cuboid-shaped particles it takes the value of $0.89 ; 1.10$ for spherical particles), $\lambda-\mathrm{X}$-ray wavelength, $\theta$-angle which is formed by the incident radiation with the atomic plane. The constant $\mathrm{K}$ was selected on the basis of the shape of particles determined by SEM and TEM microphotography.

The morphology of the obtained metal oxide nanoparticles was examined using scanning electron microscopy (SEM) and transmission electron microscopy (TEM). The investigations were carried out using Vegall-TescanCompany and Tecnai Transmission Electron Microscope, F20 $\mathrm{X}$-Twin. The Fourier Transform Infrared Spectroscopy (FT-IR) was used to determine the presence of specific functional groups in the systems studied. The FT-IR measurements were carried out using Nicolet 380 apparatus in which spectra were recorded in the range from 3900 to $400 \mathrm{~cm}^{-1}$. The sorbent surface and diameter of pores were performed (Micromeritics ASAP2010). In order to determine the energy gap width of metal oxide nanoparticles, diffuse reflectance spectroscopy was measured in the range 200-850 nm. Reflective spectra were recorded with a UV2600 spectrophotometer (Shimadzu) equipped with an integrating sphere of $10 \mathrm{~cm}$ diameter. The nature of the surface of the metal oxide nanoparticles was determined on the basis of the zeta electrokinetic potential (Malvern Instruments, ZS-90 and Brookhaven, zetaPALS).

\section{Studies on the biocatalytic properties of $\alpha$ - amylase for $\mathrm{Fe}_{3} \mathrm{O}_{4}$}

The aim of the study was to check the activity of the immobilized enzyme and its applicability as a bionanocatalytic material. The starch hydrolysis process was carried out using the obtained immobilized enzyme on the iron oxide nanoparticles. The starch solution from 1 to
$10 \mathrm{~g} / \mathrm{dm}^{3}$ was added to the iron oxide with $\alpha$-amylase and then starch distribution during time was studied. Using the magnetic properties of the carrier, the enzyme was separated from the reaction mixture. At the next stage, $10 \mathrm{ml}$ of post-reaction mixture solution was measured into a beaker, water and $0.1 \mathrm{ml}$ of $0.01 \mathrm{M} \mathrm{I}_{2}$ solution in $1 \% \mathrm{KI}$ were added. The solution was mixed on a magnetic stirrer. After 10 min the absorbance of the solution was measured on a spectrophotometer.

The kinetic parameters of this process were determined i.e. Michaelis' constant and the maximum reaction velocity was calculated from the Lineweaver-Burk equation [18]:

$\frac{1}{V}=\frac{K_{M}}{V_{\max }} \cdot \frac{1}{S}+\frac{1}{V_{\max }}$

where: V-reaction rate $\left[\mathrm{g} /\left(\mathrm{dm}^{3} \min \right)\right], \mathrm{K}_{\mathrm{M}}$-constant Michaelis-Menten $\left[\mathrm{g} / \mathrm{dm}^{3}\right], \mathrm{V}$-maximum reaction rate $[\mathrm{g} /$ $\left.\left(\mathrm{dm}^{3} \mathrm{~min}\right)\right], \mathrm{S}$ - substrate concentration $\left[\mathrm{g} / \mathrm{dm}^{3}\right]$.

\section{Studies on antimicrobial properties of $\alpha$-amylase for $\mathrm{ZnO}$}

The antimicrobial properties were studied by observing the growth of selected microorganisms from the bacterial group. The examined microorganisms were Escherichia coli, Staphylococcus aureus and Candida albicans. The test substances were: zinc oxide, zinc oxide with $\alpha$-amylase and $\alpha$-amylase. The weights containing the oxide constituted a specific percentage of the nutrient solution weight (about $15 \mathrm{~g})-0.1 \%, 0.5 \%$ and $1 \%$. The size of the weights containing the enzymes themselves was calculated taking into account the efficiency of the sorption process, so that the content of the enzyme is equal to the content of the enzyme immobilized on zinc oxide. On the dishes with prepared appropriate mediums, the weights of the tested substances were applied and then the cultures were made by surface method. Growth was observed after $24 \mathrm{~h}, 48 \mathrm{~h}$ and $72 \mathrm{~h}$ after the cultures. The tested samples with microorganisms were incubated at $30{ }^{\circ} \mathrm{C}$. The effect of materials on microorganisms was evaluated according to the given scale (Table 3).

\section{Results}

\section{Physicochemical characteristics of $\alpha$-amylases on the metal oxide nanoparticles}

The phase composition of the obtained $\mathrm{ZnO}$ and $\mathrm{Fe}_{3} \mathrm{O}_{4}$ oxides was examined using the XRD method (Fig. 2). Based on the obtained diffractogram and the Scherrer equation the average size of nanoparticle crystallites was determined using. The average size of crystallites in the 
Table 3 The assessment of bacterial and fungal growth in the presence of tested materials

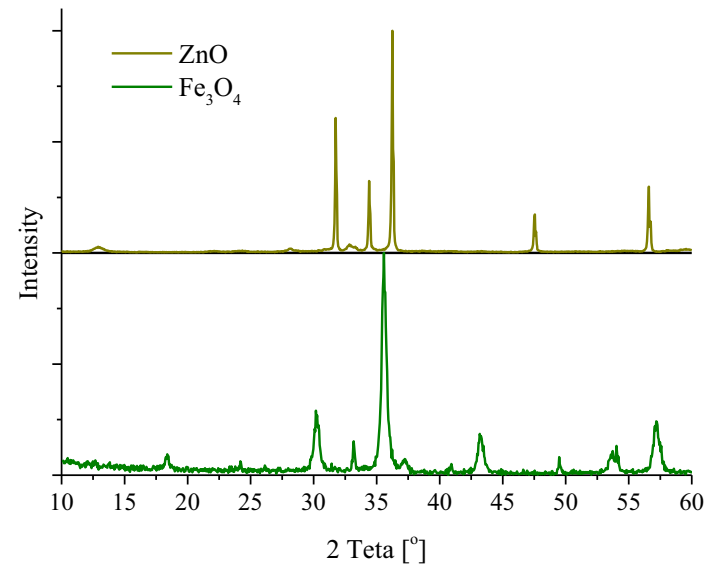

Fig. 2 Diffractogram of $\mathrm{ZnO}$ and $\mathrm{Fe}_{3} \mathrm{O}_{4}$ nanoparticles synthesised in a microwave reactor

obtained zinc oxide was $81,18 \mathrm{~nm}$ and for the iron oxide was $23.24 \mathrm{~nm}$.

The morphology of the pure metal oxide nanoparticles was studied using scanning electron microscopy and transmission electron microscopy. In Fig. 3a-f it can be observed that the zinc oxide obtained is mostly needleshaped particles. The zinc oxide nanoparticles form elongated agglomerates up to about $10 \mu \mathrm{m}$ in size. Single needles of zinc oxide are about $100 \mathrm{~nm}$ long and $5 \mathrm{~nm}$ thick. The nanoparticles of the iron oxide are spherical (Fig. $3 \mathrm{~g}-1$ ). The particle diameter is about $20 \mathrm{~nm}$. Nanoparticles do not occur in the form of agglomerates; single particles are clearly visible. The dimensions of metal oxide nanoparticles are consistent with the size of crystallites determined by XRD method.

The BET surface area of metal oxide nanoparticles was measured as $10.92 \mathrm{~m}^{2} / \mathrm{g}$ and $16.67 \mathrm{~m}^{2} / \mathrm{g}$, respectively, for $\mathrm{Fe}_{3} \mathrm{O}_{4}$ and $\mathrm{ZnO}$ nanoparticles (Table 4). The study revealed that the adsorption of enzyme molecules took place mainly on the surface of oxides, not in their pores. The small size of nanoparticles increased the effectiveness of contact with $\alpha$-amylase, without increasing the porosity of the material, so that the availability of $\alpha$-amylase was maintained. According to Pandya et al. if the enzyme is immobilized on the surface of mesoporous silica, it is immobilized only on the external surface, which results in increased activity
Assessment

No visible growth under the microscope

Growth invisible to the naked eye but clearly visible under a microscope Growth visible to the unarmed eye, covering up to $25 \%$ of the test area Growth visible to the unarmed eye, covering up to $50 \%$ of the test area Significant increase, covering more than $50 \%$ of the test area Intense growth, covering the entire test area with limited stability of the whole system. For materials with a larger pore diameter, the enzyme is immobilized inside the pores and a high increase in enzyme stability is observed [24]. An alternative method of improving system stability was given by Patel et al., who modified the surface of $\mathrm{Fe}_{3} \mathrm{O}_{4}$ nanoparticles with reduced graphene oxide. Additionally, the use of graphene oxide improved the catalytic properties of the enzyme, the activity of which increased by $192 \%$ compared to the free enzyme [25].

The $\mathrm{ZnO}$ and $\mathrm{Fe}_{3} \mathrm{O}_{4}$ nanoparticles were characterized by a positively charged surface with an electrokinetic potential of approximately $20 \mathrm{mV}$. Go et al. confirmed that the hydrodynamic radiation and zeta potentials of NPs were highly affected by sorbed compounds. The mean zeta potential of $\mathrm{ZnO}$ NPs in their study was determined to be $22.9 \pm 1.1 \mathrm{mV}$. A positively charged surface increases the binding efficiency of -COO- and $-\mathrm{NH}_{2}$ groups derived from $\alpha$-amylase [26].

The samples of zinc oxide, zinc oxide with immobilized $\alpha$-amylase, iron oxide and iron oxide with immobilized $\alpha$ amylase were examined by infrared spectroscopy (Fig. 4). The band associated with the bond $\mathrm{Zn}-\mathrm{O}$ is found at a wavelength number of approximately $465 \mathrm{~cm}^{-1}$. The band associated with the bond $\mathrm{O}-\mathrm{H}$ present in the material has been confirmed at a wavelength number of approximately $3382 \mathrm{~cm}^{-1}[27,28]$. On the spectrum obtained for zinc oxide with immobilized $\alpha$-amylase, a peak with a wavelength of $1652 \mathrm{~cm}^{-1}$ is observed, it is one of the characteristic peaks appearing in the diagrams of $\alpha$-amylase and is associated with oscillations of $\mathrm{N}-\mathrm{H}$ bonds $[29,30]$. For pure iron oxide, in the area $500-600 \mathrm{~cm}^{-1}$, bands derived from the $\mathrm{Fe}-\mathrm{O}$ bond in nanoparticles can be observed, while in the area $3400-3500 \mathrm{~cm}^{-1}$ the band is associated with the presence of hydroxyl groups derived from $\mathrm{O}-\mathrm{H}$ bonds. The FT-IR analysis showed the presence of $\alpha$ amylase immobilized on iron oxide. After adsorption of $\alpha$ amylase a new band within $1400-1500 \mathrm{~cm}^{-1}$ appeared, which may indicate amide bond. 

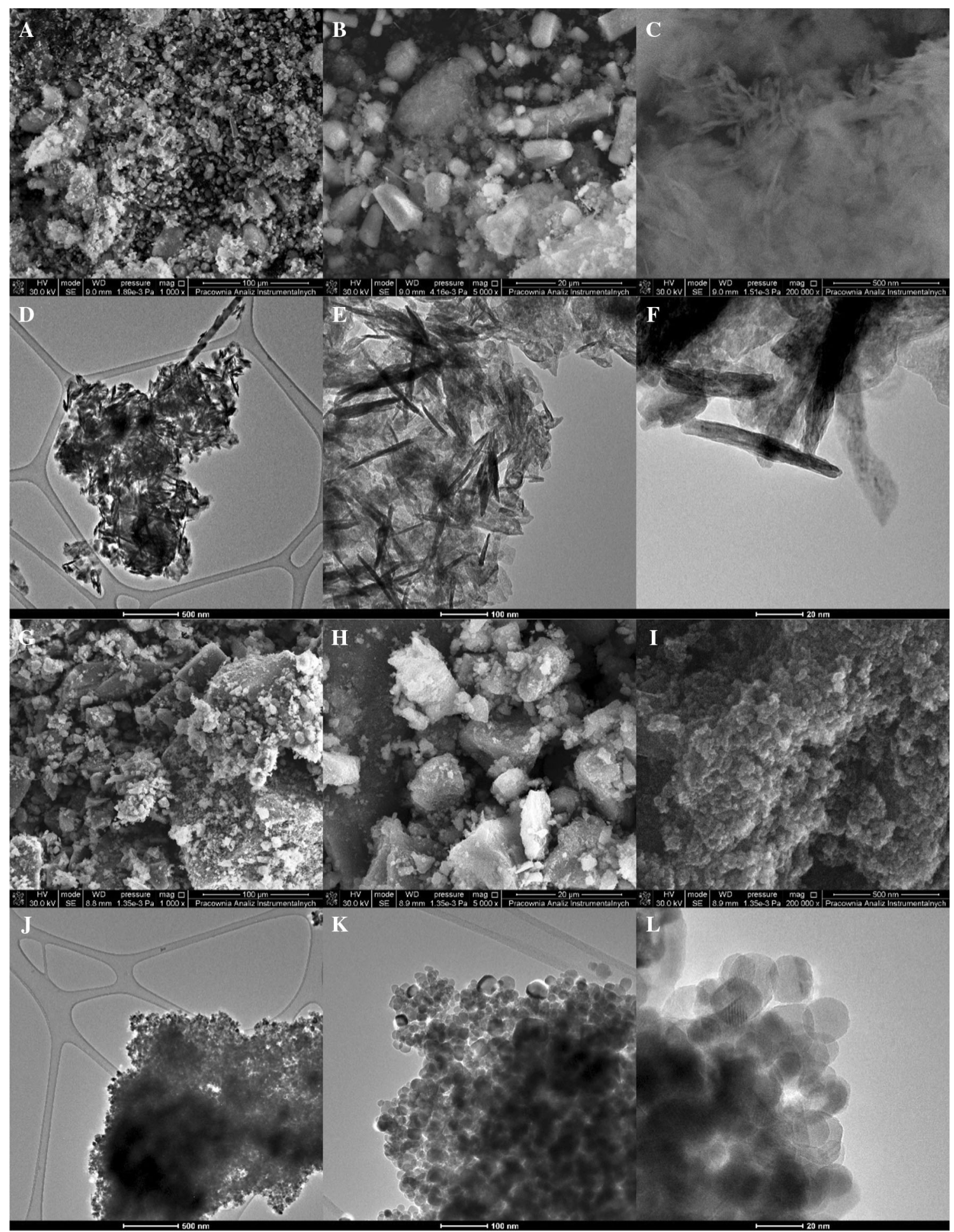

Fig. 3 The SEM microphotographs of $\mathrm{ZnO}$, extension: 3A-1 000x, 3B-5 000x, 3C-200 000x; the TEM microphotographs of $\mathrm{ZnO}$, extension: 3D-36 000x, 3E-150 000x, 3F- $750000 x$; the SEM microphotographs of $\mathrm{Fe}_{3} \mathrm{O}_{4}$, extension: 3G-1 000x, 2H-5 000x, 3I-200 000x; the TEM microphotographs of $\mathrm{Fe}_{3} \mathrm{O}_{4}$, extension: $3 \mathrm{~J}-36000 \mathrm{x}$, 3K-150 000x, 3L-750 000x; 
Table 4 Surface properties of metal oxide nanopartiecles

\begin{tabular}{lllll}
\hline & ZnO NPs & $\mathrm{ZnO}-\alpha$-amylase & $\mathrm{Fe}_{3} \mathrm{O}_{4} \mathrm{NPs}$ & $\mathrm{Fe}_{3} \mathrm{O}_{4}$ - $\alpha$-amylase \\
\hline BET Surface $\left[\mathrm{m}^{2} / \mathrm{g}\right]$ & 16.67 & - & 10.92 & - \\
Pore volume $\left[\mathrm{cm}^{3} / \mathrm{g}\right]$ & 0.07707 & - & 0.06172 & - \\
Pore size $[\mathrm{nm}]$ & 2.76 & - & 22.61 & - \\
Energy gap width & 3,54 & 3,17 & 1,96 & 1,94 \\
Electrokinetic potential $\xi[\mathrm{mV}]$ & 23.1 & 22.5 & 18.6 & 18.2 \\
\hline
\end{tabular}

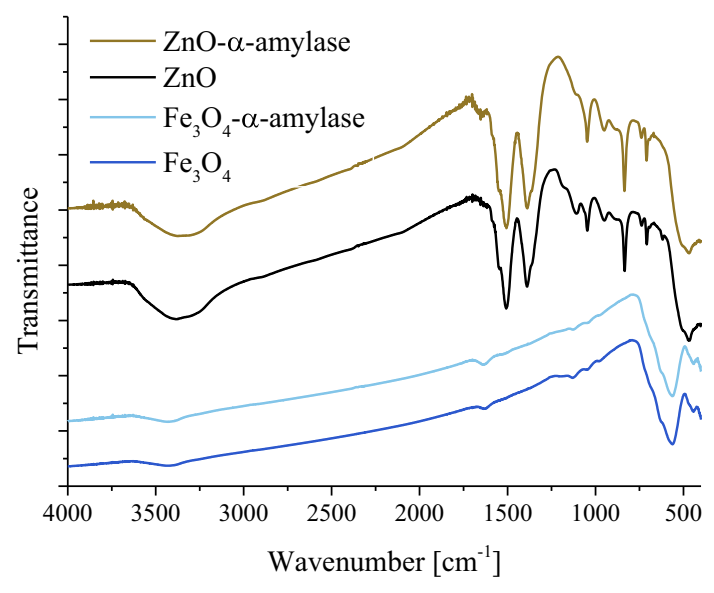

Fig. 4 Spectra of metal oxide nanoparticles and $\alpha$-amylase immobilized on the surface of metal oxide nanoparticles

\section{Immobilisation of $\alpha$-amylase on metal oxide nanoparticles}

Table 5 presents averaged results of the $\alpha$-amylase immobilization process. Figure $5 \mathrm{a}, \mathrm{b}$ presents an analysis of the effect of the examined parameters on the efficiency of the process (E) of $\alpha$-amylase immobilization on the zinc oxide. The initial concentration of the enzyme and temperature had the greatest influence on the efficiency of enzyme deposition. The efficiency of enzyme immobilization was significantly influenced by time (linearly) and interactions between temperature and time and between enzyme concentration and temperature. In the processes of obtaining $\alpha$-amylase for $\mathrm{Fe}_{3} \mathrm{O}_{4}$ the significance of the effect was confirmed for the initial enzyme concentration.

Table 5 Sorption efficiency results for $\alpha$-amylase to $\mathrm{ZnO}$ and $\alpha$-amylase to $\mathrm{Fe}_{3} \mathrm{O}_{4}$

\begin{tabular}{|c|c|c|c|c|c|c|c|}
\hline \multirow[t]{2}{*}{ L.p } & \multirow{2}{*}{$\begin{array}{l}\mathrm{C}_{\mathrm{enz}}[\mathrm{g} / \\
\left.\mathrm{dm}^{3}\right]\end{array}$} & \multirow{2}{*}{$\begin{array}{l}\mathrm{T} \\
{\left[{ }^{\circ} \mathrm{C}\right]}\end{array}$} & \multirow{2}{*}{ t } & \multicolumn{2}{|l|}{$\mathrm{ZnO}-\alpha$-amylase } & \multicolumn{2}{|l|}{$\mathrm{Fe}_{3} \mathrm{O}_{4}-\alpha$-amylase } \\
\hline & & & & $\begin{array}{l}\text { Sorption efficiency E } \\
{[\%]}\end{array}$ & $\begin{array}{l}\text { Sorption capacity [mg/ } \\
\mathrm{g}]\end{array}$ & $\begin{array}{l}\text { Sorption efficiency E } \\
{[\%]}\end{array}$ & $\begin{array}{l}\text { Sorption capacity [mg/ } \\
\mathrm{g}]\end{array}$ \\
\hline 1 & 0.1 & 20 & 30 & $\geq 99.99$ & $6.27 \pm 0.3$ & $92.81 \pm 12.46$ & $6.27 \pm 0.33$ \\
\hline 2 & 0.1 & 20 & 120 & $\geq 99.99$ & $6.66 \pm 0.0$ & $99.94 \pm 0.11$ & $7.99 \pm 0.81$ \\
\hline 3 & 0.1 & 25 & 75 & $\geq 99.99$ & $6.68 \pm 0.0$ & $99.91 \pm 0.15$ & $6.37 \pm 0.54$ \\
\hline 4 & 0.1 & 30 & 30 & $\geq 99.99$ & $6.27 \pm 0.4$ & $97.03 \pm 5.14$ & $7.15 \pm 0.70$ \\
\hline 5 & 0.1 & 30 & 120 & $\geq 99.99$ & $6.68 \pm 0.0$ & $78.93 \pm 12.14$ & $85.46 \pm 22.32$ \\
\hline 6 & 0.5 & 20 & 75 & $94.68 \pm 0.76$ & $50.37 \pm 0.7$ & $86.78 \pm 1.07$ & $102.9 \pm 12.26$ \\
\hline 7 & 0.5 & 25 & 30 & $95.96 \pm 2.53$ & $51.18 \pm 2.3$ & $83.12 \pm 1.66$ & $83.13 \pm 3.28$ \\
\hline 8 & 0.5 & 25 & 75 & $97.68 \pm 2.09$ & $51.98 \pm 2.0$ & $85.20 \pm 2.22$ & $89.75 \pm 3.19$ \\
\hline 9 & 0.5 & 25 & 75 & $96.92 \pm 2.91$ & $51.49 \pm 2.5$ & $99.99 \pm 0.01$ & $7.75 \pm 3.28$ \\
\hline 10 & 0.5 & 25 & 120 & $\geq 99.99$ & $54.17 \pm 0.2$ & $88.22 \pm 6.05$ & $86.63 \pm 15.10$ \\
\hline 11 & 0.5 & 30 & 75 & $97.26 \pm 3.25$ & $46.22 \pm 4.1$ & $94.05 \pm 9.24$ & $47.10 \pm 4.11$ \\
\hline 12 & 1.0 & 20 & 30 & $86.35 \pm 1.38$ & $85.56 \pm 0.8$ & $85.96 \pm 1.49$ & $44.48 \pm 2.40$ \\
\hline 13 & 1.0 & 20 & 120 & $96.20 \pm 2.81$ & $100.8 \pm 8.2$ & $90.49 \pm 1.14$ & $46.12 \pm 1.52$ \\
\hline 14 & 1.0 & 25 & 75 & $93.79 \pm 2.05$ & $97.31 \pm 7.4$ & $92.84 \pm 6.28$ & $48.35 \pm 5.45$ \\
\hline 15 & 1.0 & 30 & 30 & $98.77 \pm 0.54$ & $98.12 \pm 0.7$ & $91.94 \pm 10.60$ & $48.03 \pm 7.35$ \\
\hline 16 & 1.0 & 30 & 120 & $94.77 \pm 4.57$ & $99.44 \pm 12.1$ & $93.26 \pm 6.24$ & $48.58 \pm 5.23$ \\
\hline
\end{tabular}




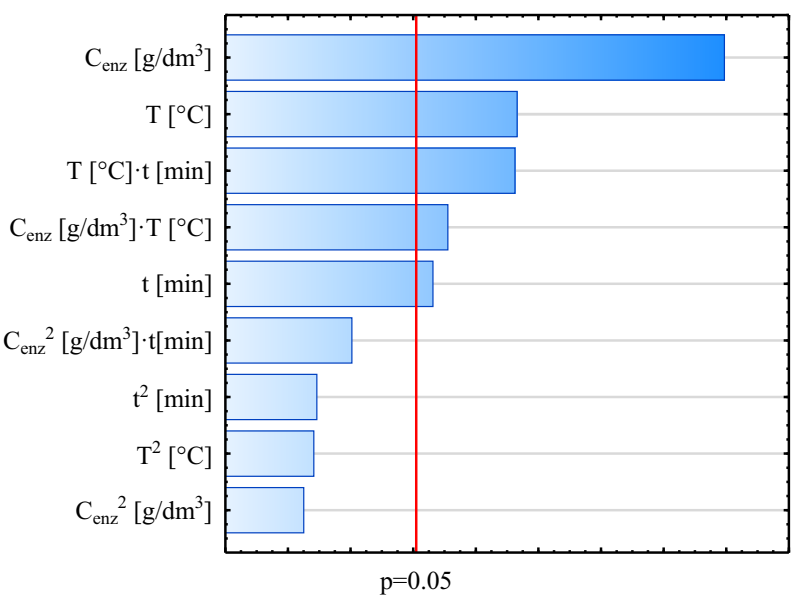

(a)

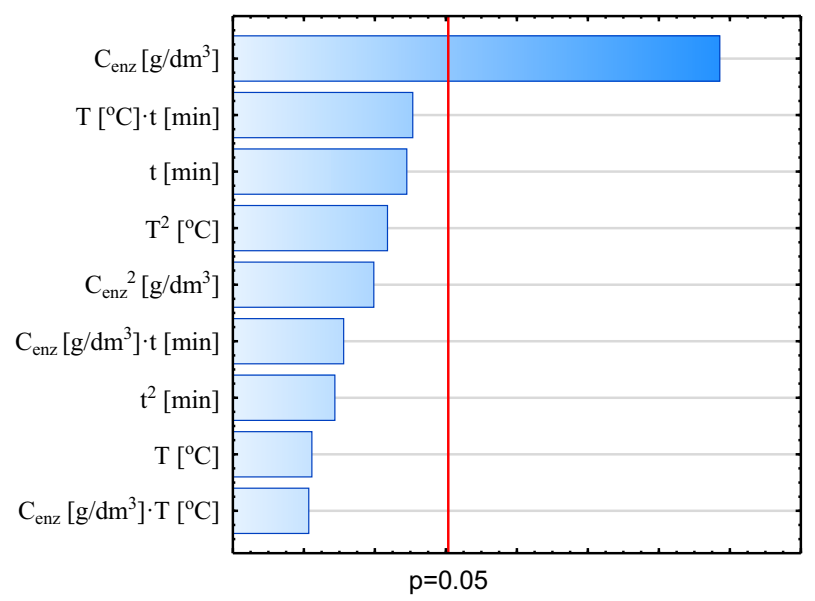

(c)

Fig. 5 Parameters significantly influencing the efficiency of the process (E) of $\alpha$-amylase immobilization: a, $\mathbf{b}$ immobilization of $\alpha$ amylase on $\mathrm{ZnO}$ (significance level equal to $5 \%$ ) and approximation

It was found that the most optimal process parameters are: enzyme concentration equal to $1 \mathrm{~g} / \mathrm{dm}^{3}$, temperature $30{ }^{\circ} \mathrm{C}$ and time of $120 \mathrm{~min}$. The conditions ensure optimal immobilization efficiency, with the maximum amount of immobilized enzyme. The amount of absorbed protein increases significantly with the concentration, despite the reduced efficiency of sorption. A higher process temperature increases the efficiency of the process without significantly affecting the amount of absorbed enzyme. On the basis of the results, sorption of the enzyme to $\mathrm{Fe}_{3} \mathrm{O}_{4}$ was carried out in the most favourable conditions, i.e. temperature at $20{ }^{\circ} \mathrm{C}$ for $120 \mathrm{~min}$ in the enzyme solution of $1 \mathrm{~g} /$ $\mathrm{dm}^{3}$ concentration.

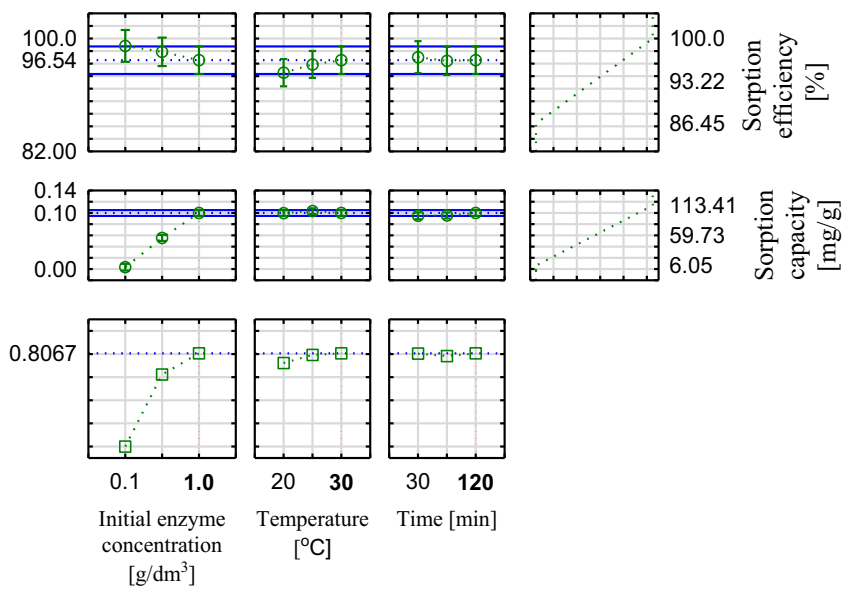

(b)
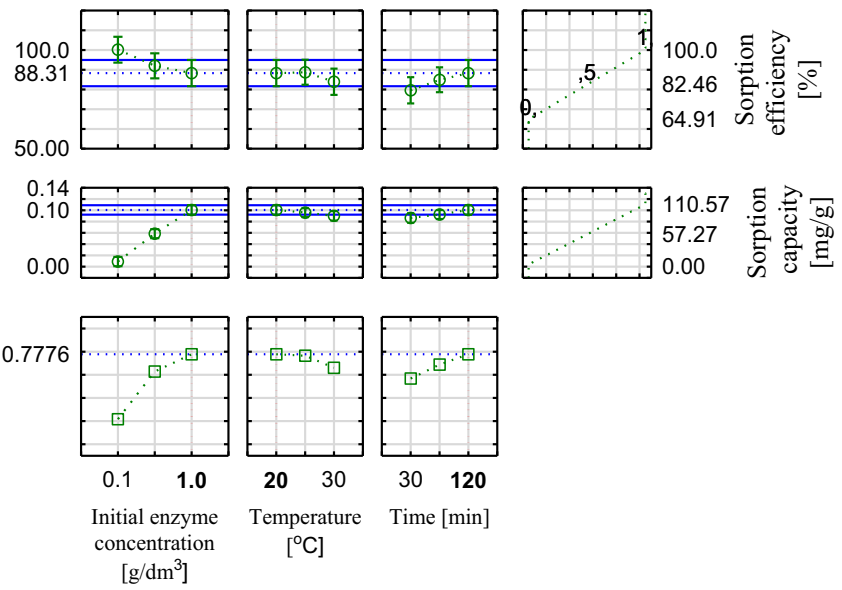

(d)

profile of predicted values; $\mathbf{c}, \mathbf{d}$ immobilization of $\alpha$-amylase on $\mathrm{Fe}_{3} \mathrm{O}_{4}$ and approximation profile of predicted values

\section{Kinetic and equilibrium parameters of the $\alpha$ - amylase immobilisation process}

Based on the results, the parameters of sorption equilibrium of the enzyme on the surface of the metal oxides were determined (Table 6). For both oxides, Langmuir isotherm has the highest coefficients of determination. The Langmuir isotherm describes the chemical adsorption which results in a single-molecular layer of the sorbent [22]. The high determination factor for Freundlich's isotherm, which concerns multilayer physical adsorption on microporous materials has also been confirmed for $\alpha$-amylase deposition on $\mathrm{ZnO}$ [21]. It can be concluded that the sorption process of $\alpha$-amylase on zinc oxide is a complex process, following the assumptions of these two models (Fig. 6). The analysis of the kinetics of enzyme immobilization processes confirmed the chemical nature of the processes. The sorption 
Table 6 The equilibrium and the kinetics parameters of the $\alpha$-amylase immobilisation process on the metal oxides nanoparticles

\begin{tabular}{|c|c|c|c|c|c|c|c|}
\hline \multicolumn{2}{|c|}{ Equilibrium models sorption processes } & \multirow{2}{*}{$\begin{array}{l}\begin{array}{l}\mathrm{ZnO}- \\
\alpha \text {-amylase }\end{array} \\
427.8\end{array}$} & \multirow{2}{*}{$\begin{array}{l}\mathrm{Fe}_{3} \mathrm{O}_{4^{-}} \\
\alpha \text {-amylase }\end{array}$} & \multicolumn{2}{|c|}{ Kinetics models sorption processes } & \multirow{2}{*}{$\begin{array}{l}\begin{array}{l}\mathrm{ZnO}- \\
\alpha \text {-amylase }\end{array} \\
0.015203\end{array}$} & \multirow{2}{*}{$\begin{array}{l}\mathrm{Fe}_{3} \mathrm{O}_{4^{-}} \\
\alpha \text {-amylase }\end{array}$} \\
\hline Langmuir & $q_{\max }$ & & & Pseudo-first order & $k_{I}$ & & \\
\hline & $K_{L}$ & 0.2936 & 0.4534 & & $q_{\max }$ & 47.5335 & 25.6109 \\
\hline & $R^{2}$ & 0.9992 & 0.9993 & & $R^{2}$ & 0.9505 & 0.7261 \\
\hline \multirow[t]{3}{*}{ Freundlich } & $K_{F}$ & 98.99 & 92.27 & Pseudo-second order & $k_{I I}$ & 2.1606 & 2.3222 \\
\hline & $n$ & 1.1381 & 0.9399 & & $q_{\max }$ & 101.53 & 103.87 \\
\hline & $R^{2}$ & 0.9991 & 0.9882 & & $R^{2}$ & 0.9903 & 0.9746 \\
\hline \multirow[t]{6}{*}{ Temkin } & $A_{T}$ & 6.3396 & 9.4548 & Elovich & $\alpha$ & 0.9617 & 6.99 \\
\hline & $b_{T}$ & 46.2778 & 64.5844 & & $\beta$ & 20.87 & 91.743 \\
\hline & $R^{2}$ & 0.9726 & 0.9139 & & $R^{2}$ & 0.9364 & 0.7211 \\
\hline & & & & Intramolecular diffusion & $k_{i d}$ & 0.4583 & 0.5226 \\
\hline & & & & & $a$ & 0.2181 & 0.1196 \\
\hline & & & & & $R^{2}$ & 0.9404 & 0.7851 \\
\hline
\end{tabular}

Fig. 6 Plots of $\alpha$-amylase isothermal equilibrium sorption on metal oxide nanoparticles: a sorption of $\alpha$-amylase on $\mathrm{ZnO}$ nanoparticles, b sorption of $\alpha$ amylase on $\mathrm{Fe}_{3} \mathrm{O}_{4}$ nanoparticles

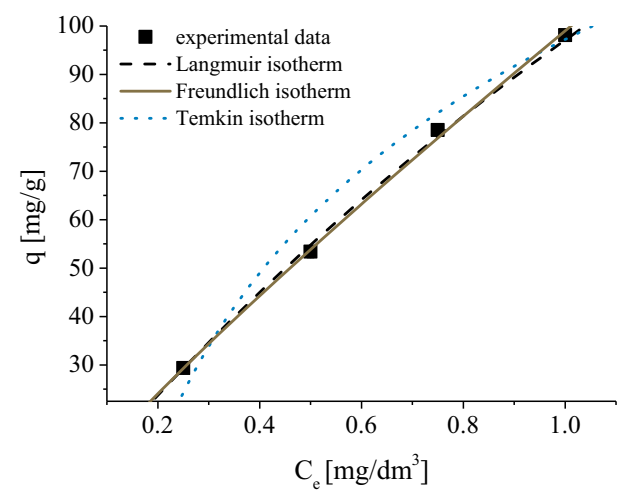

(a)

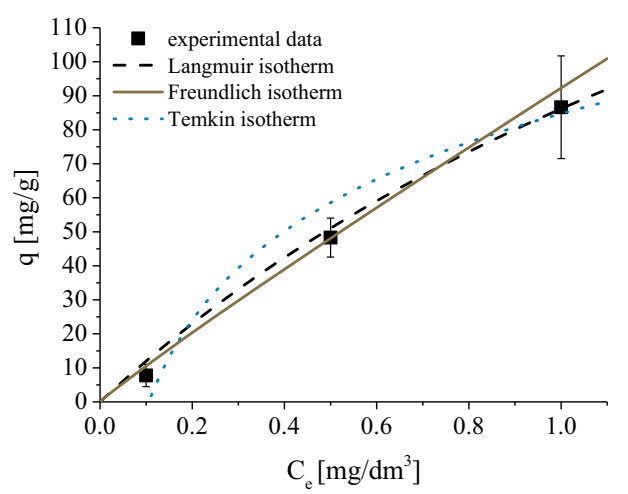

(b) processes of $\alpha$-amylase to $\mathrm{ZnO}$ and $\mathrm{Fe}_{3} \mathrm{O}_{4}$ were carried out according to the kinetics of the pseudo-second order, which additionally confirms the advantage of chemical nature of the enzyme sorption. On the basis of the literature it was found that mainly carboxylic and amino groups take part in the binding of enzymes to the surface of oxides. The presence of polar groups such as carboxylic $(-\mathrm{COOH})$, phosphate $\left(-\mathrm{PO}(\mathrm{OH})_{2}\right)$, amino $\left(-\mathrm{NH}_{2}\right)$, and thiol $(-\mathrm{SH})$ groups anchor the molecule on the surface of metal oxides such as $\mathrm{ZnO}$. The $\mathrm{ZnO}$ surface is characterized by the polar part resulting from the presence of oxygen and the neutral part associated with the presence of $\mathrm{Zn}$. The carboxylic groups present in amylase bind to the oxide through dissociative adsorption through dissociated hydrogen atom with surface oxygen, while amine and hydroxyl groups tend to bind non-associative [31, 32]. Kahraman et al. confirmed the $\alpha$-amylase bonding by the covalent bonds immobilized on glass beads containing phthalicol chloride. The functioning of the carrier surface with amine groups caused prolongation of the enzyme activity. Higher thermostability compared to free enzyme particles was also confirmed [33]. Pandya et al. observed the significance of the $\alpha$-amylase deposition site for its activity [24].

\section{The catalytic properties $\alpha$-amylases on $\mathrm{Fe}_{3} \mathrm{O}_{4}$}

The catalytic properties of $\alpha$-amylases were tested by hydrolysis of starch. The plot of starch decomposition over time is presented in Fig. 7a. The kinetic parameters of the reaction were determined after the hydrolysis of starch. The concentration of hydrolysis product (S) was calculated, based on the concentration of starch remaining in the system. Next, a diagram $1 / \mathrm{S}$ from $1 / \mathrm{t}$ was plotted, which is presented in Fig. 7b. This graph represents the Lineweaver-Burk equation. On the basis of the function equation the constant of $\mathrm{K}_{\mathrm{M}}$ reaction rate $=0.7799\left[\mathrm{~g} / \mathrm{dm}^{3}\right]$ and the maximum reaction rate $\mathrm{V}_{\max }=8.660\left[\mathrm{~g} /\left(\mathrm{dm}^{3} \min \right)\right]$ were calculated. Despite the limited mobility of the 
Fig. 7 a The starch concentration during hydrolysis in the presence of the $\mathrm{Fe}_{3} \mathrm{O}_{4}-\alpha$ amylase, $\mathbf{b}$ The rate of starch hydrolysis in the presence of the $\mathrm{Fe}_{3} \mathrm{O}_{4}$ - $\alpha$-amylase

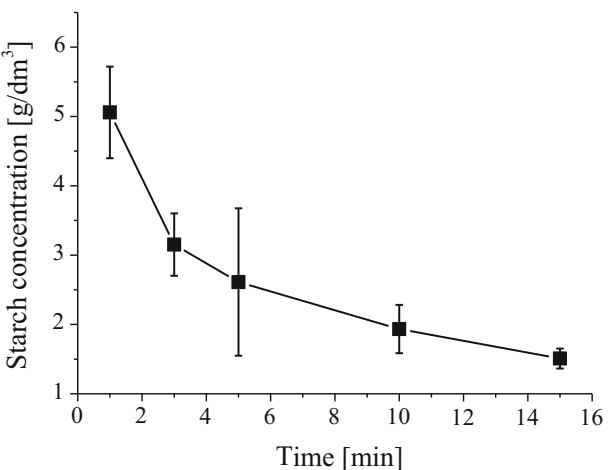

(a)

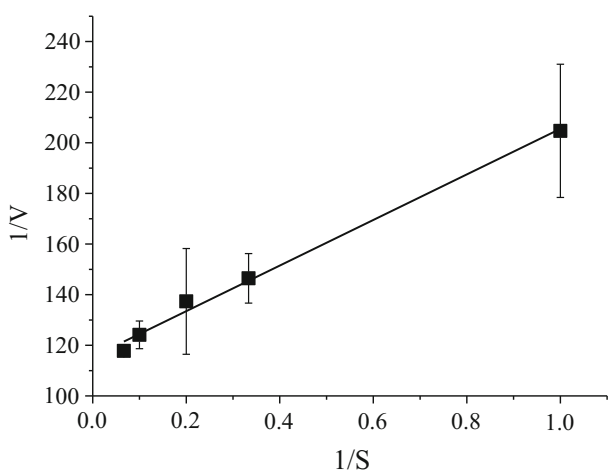

(b) enzyme and contact with the reagent, the immobilization of $\alpha$-amylase on the carrier surface increases the reaction area and preserves the efficiency of the catalytic process.

The effectiveness of $\alpha$-amylase combined with the carrier was confirmed by Salaonkar et al. comparing the effectiveness of hydrolysis distribution. The constant reaction rate for the bound enzyme was $0.5889 \mu \mathrm{mol} / \mathrm{dm}^{3}$ which is consistent with the results obtained in the presented study. Compared to the reaction carried out in the presence of a free enzyme, the value of both the constant and the maximum reaction rate was comparable, which confirmed the effectiveness of deposition of the enzyme on a carrier without loss of its activity [34].

\section{Antimicrobial properties}

The antimicrobial properties of $\mathrm{ZnO}-\alpha$-amylase, pure zinc oxide and pure enzyme as reference samples were tested. Table 7 summarises the data obtained in the study. The antimicrobial activity of zinc oxide nanoparticles and $\alpha$ amylase on $\mathrm{ZnO}$ nanoparticles surfaces was confirmed. The zinc oxide showed antimicrobial properties against bacteria both gram positive and gram negative. The fungicidal properties of nanoparticles were limited. Azizi-Lalabadi et al. proved that the antimicrobial activity of $\mathrm{ZnO}$ nanoparticles is dependent on the species of microorganism (gram positive or gram negative). The sensitive microorganisms were gram negative bacteria, i.e. P. fluorescens, and E. coli [35].

Both $\mathrm{Zn}^{2+}$ particles and $\mathrm{ZnO}$ nanoparticles have an antibacterial effect. The nanoparticles reveal biocidal activity for two mechanisms: as a result of free metal ion toxicity resulting from dissolution of metals from the surface of the nanoparticles and generation of oxidative stress through generation of reactive oxygen species (ROS) using hydrogen peroxide $\left(\mathrm{H}_{2} \mathrm{O}_{2}\right)$ on the surface of the nanoparticles. Additionally, nanoparticles can affect the viability of microorganisms by agglomeration on the surface of bacteria and change the structure of lipids, peptidoglycans, proteins and their DNA [36].

In the presented studies, $\alpha$-amylase itself demonstrated absence of antimicrobial activity. However, the addition of $\alpha$-amylase improved the bioactivity of $\mathrm{ZnO}$ NPs. The enzyme catalyses the hydrolysis of the internal $\alpha$-1,4-glycosidic bonds in starch, transforming starch into low molecular weight products such as glucose, maltose and maltotriose compounds. The basic components of the cell membrane are lipids and proteins which together make up 60 to $80 \%$. The remaining part is made up of sugars, which are bound to lipids and proteins forming glycolipids and glycoproteins. The $\alpha$-amylase affects the decomposition of sugars; however, it is only when combined with zinc oxide nanoparticles that the cell membrane of microorganisms is destroyed, thus deactivating them. Therefore, it is beneficial to obtain a complex compound with synergistic properties. Date described the process of glycoprotein breakdown using $\alpha$-amylase confirming its effectiveness [37].

The activity of the composite results from the effectiveness of the connection between the components. Excessive release of $\alpha$-amylase would reduce contact between $\mathrm{ZnO}$ and the enzyme and the activity of such a system would be equal to the pure $\mathrm{ZnO}$. Anthony et al. confirmed the synergistic effects of amylase with nanoparticles on the example of silver nanoparticles. Despite the confirmed antimicrobial properties of Ag NPs, the connection of the material with the enzyme additionally increases the activity of silver nanoparticles [38]. Cui et al. by modifying the surface of $\mathrm{Fe}_{3} \mathrm{O}_{4}$ with silica received a material with an inactive surface, which protected the catalase from biological, thermal and chemical degradation. However, the inactive surface inhibited activity of the carrier [39]. Homaei and Saberi successfully immobilized $\alpha$-amylase on gold nanoparticles while maintaining temperature stability compared to free $\alpha$-amylase. The enzyme also showed higher activity than the free form. Due to the improved stability of the enzyme on the surface of gold 
Table 7 The antimicrobial properties of $\mathrm{ZnO}, \mathrm{ZnO}-\alpha-$ amylase and $\alpha$-amylase for E. coli, S. aureus and $C$. albicans

\begin{tabular}{|c|c|c|c|c|c|c|c|c|c|c|c|c|c|c|c|c|c|c|}
\hline \multirow{4}{*}{$\begin{array}{l}\mathrm{C}_{\mathrm{p}}[\%] \\
\mathrm{t}[\mathrm{h}]\end{array}$} & \multicolumn{6}{|c|}{ E. coli } & \multicolumn{6}{|c|}{ S. aureus } & \multicolumn{6}{|c|}{ C. albicans } \\
\hline & \multicolumn{6}{|c|}{$\mathrm{ZnO}$} & \multicolumn{6}{|c|}{$\mathrm{ZnO}$} & \multicolumn{6}{|c|}{$\mathrm{ZnO}$} \\
\hline & \multicolumn{2}{|c|}{$0.1 \%$} & \multicolumn{2}{|c|}{$0.5 \%$} & \multicolumn{2}{|c|}{$1.0 \%$} & \multicolumn{2}{|c|}{$0.1 \%$} & \multicolumn{2}{|c|}{$0.5 \%$} & \multicolumn{2}{|c|}{$1.0 \%$} & \multicolumn{2}{|c|}{$0.1 \%$} & \multicolumn{2}{|c|}{$0.5 \%$} & \multicolumn{2}{|c|}{$1.0 \%$} \\
\hline & A & B & A & B & A & B & A & B & A & B & A & B & A & B & A & B & A & B \\
\hline 24 & 2 & 2 & 2 & 1 & 0 & 0 & 0 & 1 & 0 & 1 & 0 & 0 & 3 & 3 & 3 & 3 & 3 & 3 \\
\hline 48 & 2 & 2 & 2 & 1 & 0 & 0 & 2 & 2 & 2 & 3 & 2 & 2 & 3 & 3 & 4 & 4 & 4 & 4 \\
\hline 72 & 2 & 2 & 2 & 1 & 0 & 0 & 3 & 3 & 2 & 3 & 3 & 2 & 4 & 4 & 4 & 4 & 4 & 4 \\
\hline \multirow[t]{2}{*}{$\mathrm{C}_{\mathrm{p}}[\%]$} & \multicolumn{6}{|c|}{$\mathrm{ZnO}+\alpha$-amylase } & \multicolumn{6}{|c|}{$\mathrm{ZnO}+\alpha$-amylase } & \multicolumn{6}{|c|}{$\mathrm{ZnO}+\alpha$-amylase } \\
\hline & \multicolumn{2}{|c|}{$0.1 \%$} & \multicolumn{2}{|c|}{$0.5 \%$} & \multicolumn{2}{|c|}{$1.0 \%$} & \multicolumn{2}{|c|}{$0.1 \%$} & \multicolumn{2}{|c|}{$0.5 \%$} & \multicolumn{2}{|c|}{$1.0 \%$} & \multicolumn{2}{|c|}{$0.1 \%$} & \multicolumn{2}{|c|}{$0.5 \%$} & \multicolumn{2}{|c|}{$1.0 \%$} \\
\hline $\mathrm{t}[\mathrm{h}]$ & A & B & A & B & A & B & A & B & A & B & A & B & A & B & A & B & A & B \\
\hline 24 & 0 & 0 & 0 & 0 & 0 & 0 & 0 & 0 & 0 & 0 & 0 & 0 & 3 & 3 & 3 & 3 & 3 & 3 \\
\hline 48 & 1 & 1 & 1 & 1 & 0 & 0 & 1 & 2 & 1 & 1 & 1 & 1 & 3 & 3 & 4 & 3 & 4 & 3 \\
\hline 72 & 1 & 2 & 2 & 1 & 0 & 0 & 3 & 3 & 2 & 2 & 2 & 2 & 4 & 4 & 4 & 4 & 4 & 4 \\
\hline $\mathrm{C}_{\mathrm{p}}[\%]$ & \multicolumn{6}{|c|}{$\alpha$-Amylase } & $\alpha-$ & myl & & & & & & myı & & & & \\
\hline & 0.1 & & 0.5 & & 1.0 & & 0.1 & & 0.5 & & 1. & & 0. & & 0.5 & & & \\
\hline $\mathrm{t}[\mathrm{h}]$ & A & B & A & B & A & B & A & B & A & B & A & B & A & B & A & B & A & B \\
\hline 24 & 2 & 2 & 2 & 2 & 2 & 2 & 3 & 3 & 3 & 3 & 3 & 3 & 3 & 3 & 3 & 3 & 3 & 3 \\
\hline 48 & 2 & 2 & 2 & 2 & 2 & 2 & 3 & 3 & 4 & 3 & 4 & 3 & 4 & 4 & 4 & 4 & 4 & 4 \\
\hline 72 & 2 & 2 & 2 & 2 & 2 & 2 & 4 & 4 & 4 & 4 & 4 & 4 & 4 & 4 & 4 & 4 & 4 & 4 \\
\hline
\end{tabular}

nanoparticles, the authors confirmed the possibility of using the material in industry as a biocatalyst for the production of glucose syrups on an industrial scale [13].

\section{Conclusion}

In the processes of $\alpha$-amylase immobilization on the surface of metal oxide nanoparticles $\mathrm{ZnO}-\alpha$-amylase and $\mathrm{Fe}_{3} \mathrm{O}_{4}-\alpha$-amylase materials were obtained.

In the processes of immobilization of the enzyme on the $\mathrm{ZnO}$ surface, the initial concentration of the enzyme, process time and its temperature showed to be important parameters. The most effective parameters of $\alpha$-amylase immobilization on zinc oxide were determined, obtaining $96.20 \%$ efficiency of the enzyme sorption process and $100.8 \mathrm{mg} / \mathrm{g}$ carrier. The process of enzyme immobilization is complex-there is chemical adsorption and multilayer physical adsorption. Antimicrobial properties of prepared amylase from $\mathrm{ZnO}$ result from synergic action of zinc oxide nanoparticles with the enzyme, and $\alpha$-amylase itself did not show antimicrobial properties.

In $\mathrm{Fe}_{3} \mathrm{O}_{4}$ - $\alpha$-amylase systems the obtained iron oxide particles had magnetic properties. By using iron oxide nanoparticles with magnetic properties, it is possible to separate the biocatalyst from the reaction system. The most favourable parameters for sorption of $\alpha$-amylase to $\mathrm{Fe}_{3} \mathrm{O}_{4}$ were: temperature $20{ }^{\circ} \mathrm{C}$, concentration of enzyme solution $1 \mathrm{~g} / \mathrm{dm}^{3}$, sorption time $120 \mathrm{~min}$. In the studies on the deposition of the enzyme on the surface of metal oxide nanoparticles, the equilibrium and kinetics parameters of the process were determined, based on which the chemical character of the enzyme immobilization was found. The model of pseudo-second order kinetics was characterized by the best fit $\left(\mathrm{R}^{2}\right)$ for $\mathrm{Fe}_{3} \mathrm{O}_{4}-\alpha$-amylase. This indicated that chemisorption was taking place. The Langmuir isotherm showed the best fit for the study. The parameters of starch hydrolysis process indicated the catalytic activity of the enzyme immobilized on $\mathrm{Fe}_{3} \mathrm{O}_{4}$ nanoparticles.

Funding This research did not receive any specific grant from funding agencies in the public, commercial, or not-for-profit sector.

\section{Compliance with ethical standards}

Conflict of interest The authors report no declarations of interest. 
Open Access This article is licensed under a Creative Commons Attribution 4.0 International License, which permits use, sharing, adaptation, distribution and reproduction in any medium or format, as long as you give appropriate credit to the original author(s) and the source, provide a link to the Creative Commons licence, and indicate if changes were made. The images or other third party material in this article are included in the article's Creative Commons licence, unless indicated otherwise in a credit line to the material. If material is not included in the article's Creative Commons licence and your intended use is not permitted by statutory regulation or exceeds the permitted use, you will need to obtain permission directly from the copyright holder. To view a copy of this licence, visit http://creativecommons. org/licenses/by/4.0/.

\section{References}

1. L. Jajpura, "Enzyme: A Bio Catalyst for Cleaning up Textile and Apparel Sector," Springer, Singapore, 2018, pp. 95-137.

2. P. D. Tomke and V. K. Rathod, "Enzyme as biocatalyst for synthesis of octyl ethanoate using acoustic cavitation: Optimization and kinetic study," Biocatal. Agric. Biotechnol., vol. 7, pp. 145-153, Jul. 2016.

3. M. B. Quin, K. K. Wallin, G. Zhang, and C. Schmidt-Dannert, "Spatial organization of multi-enzyme biocatalytic cascades," Org. Biomol. Chem., vol. 15, no. 20, pp. 4260-4271, May 2017.

4. R. K. Murray, D. K. Granner, P. A. Mayes, and V. W. Rodwell (1994) Biochemia Harpera.

5. S. A. Mohamed, M. H. Al-Harbi, Y. Q. Almulaiky, I. H. Ibrahim, and R. M. El-Shishtawy, "Immobilization of horseradish peroxidase on Fe3O4 magnetic nanoparticles," Electron. J. Biotechnol., vol. 27, pp. 84-90, May 2017.

6. J. Juhász, Z. Gáspári, and S. Pongor, "Structure and Oxidative Folding of AAI, the Major Alfa-Amylase Inhibitor From Amaranth Seeds," Front. Chem., vol. 8, p. 180, Mar. 2020.

7. I. DeFelipe, J. A. Pulgar, and D. Pedreira, "Crustal structure of the eastern Basque-cantabrian zone - Western Pyrenees: From the Cretaceous hyperextension to the Cenozoic inversion," Rev. la Soc. Geol. Espana, vol. 31, no. 2, pp. 69-82, 2018.

8. K. R. Aadil, N. Pandey, S. I. Mussatto, and H. Jha, "Green synthesis of silver nanoparticles using acacia lignin, their cytotoxicity, catalytic, metal ion sensing capability and antibacterial activity," J. Environ. Chem. Eng., vol. 7, no. 5, p. 103296, Oct. 2019.

9. J. Zdarta, A. Meyer, T. Jesionowski, and M. Pinelo, "A General Overview of Support Materials for Enzyme Immobilization: Characteristics, Properties, Practical Utility," Catalysts, vol. 8, no. 2, p. 92, Feb. 2018.

10. G. R. VandeZande, J. M. Olvany, J. L. Rutherford, and M. Rasmussen, "Enzyme Stabilization and Immobilization IN Series Editor," Enzym. Stab. Immobil., vol. 1504, pp. 165-179, 2017.

11. T. Pradubsang, N. Patikarnmonthon, and T. Amornsakchai (2018) Utilization of cellulose microfiber from pineapple leaf as lipase immobilization support for highly retained activity, ease of separation and reusability Porcine placenta extract for cosmetics applications View project Cotton-based cellulose for developme.

12. R. Ahmad, M. Mohsin, T. Ahmad, and M. Sardar, "Alpha amylase assisted synthesis of $\mathrm{TiO} 2$ nanoparticles: Structural characterization and application as antibacterial agents," $J$. Hazard. Mater., vol. 283, pp. 171-177, Feb. 2015.

13. A. Homaei and D. Saberi, "Immobilization of $\alpha$-amylase on gold nanorods: An ideal system for starch processing," Process Biochem., vol. 50, no. 9, pp. 1394-1399, Jul. 2015.

14. S. H. Bang et al., "Antimicrobial properties of lysosomal enzymes immobilized on $\mathrm{NH} 2$ functionalized silica-encapsulated magnetite nanoparticles," J. Nanosci. Nanotechnol., vol. 16, no. 1, pp. 1090-1094, Jan. 2016.

15. L. P. Datta, A. Chatterjee, K. Acharya, P. De, and M. Das, "Enzyme responsive nucleotide functionalized silver nanoparticles with effective antimicrobial and anticancer activity," New J. Chem., vol. 41, no. 4, pp. 1538-1548, Feb. 2017.

16. C. M. Kahler, M. Sarkar-Tyson, E. A. Kibble, K. A. Stubbs, and A. Vrielink, "Enzyme targets for drug design of new anti-virulence therapeutics," Current Opinion in Structural Biology, vol. 53. Elsevier Ltd, pp. 140-150, 01-Dec-2018.

17. B. Varga, V. Somogyi, M. Meiczinger, N. Kováts, and E. Domokos, "Enzymatic treatment and subsequent toxicity of organic micropollutants using oxidoreductases - A review," $J$. Clean. Prod., vol. 221, pp. 306-322, Jun. 2019.

18. R. A. Meryam Sardar, "Enzyme Immobilization: An Overview on Nanoparticles as Immobilization Matrix," Biochem. Anal. Biochem., vol. 04, no. 02, 2015.

19. S. Datta, L. R. Christena, and Y. R. S. Rajaram, "Enzyme immobilization: an overview on techniques and support materials," 3 Biotech, vol. 3, no. 1, pp. 1-9, 2013.

20. O. M. Darwesh, I. A. Matter, and M. F. Eida, "Development of peroxidase enzyme immobilized magnetic nanoparticles for bioremediation of textile wastewater dye," J. Environ. Chem. Eng., vol. 7, no. 1, p. 102805, 2019.

21. T. Carvalho, A. da S. Pereira, R. C. F. Bonomo, M. Franco, P. V. Finotelli, and P. F. F. Amaral, "Simple physical adsorption technique to immobilize Yarrowia lipolytica lipase purified by different methods on magnetic nanoparticles: Adsorption isotherms and thermodynamic approach," Int. J. Biol. Macromol., vol. 160, pp. 889-902, Oct. 2020.

22. K. Singh, A. Mishra, D. Sharma, and K. Singh, "Nanotechnology in Enzyme Immobilization: An Overview on Enzyme Immobilization with Nanoparticle Matrix," Curr. Nanosci., vol. 15, no. 3, pp. 234-241, Oct. 2018.

23. O. Lowry, N. Rosebrough, A. L. Farr, and R. Randall, "Protein measurement with the Folin phenol reagent," J. Biol. Chem., vol. 193, pp. 265-275, 1951.

24. P. H. Pandya, R. V. Jasra, B. L. Newalkar, and P. N. Bhatt, "Studies on the activity and stability of immobilized $\alpha$-amylase in ordered mesoporous silicas," Microporous Mesoporous Mater., vol. 77, no. 1, pp. 67-77, Jan. 2005.

25. S. K. S. Patel, S. H. Choi, Y. C. Kang, and J. K. Lee, "Ecofriendly composite of $\mathrm{Fe} 3 \mathrm{O} 4$-reduced graphene oxide particles for efficient enzyme immobilization," ACS Appl. Mater. Interfaces, vol. 9, no. 3, pp. 2213-2222, Jan. 2017.

26. M. R. Go, J. Yu, S. H. Bae, H. J. Kim, and S. J. Choi, "Effects of interactions between $\mathrm{ZnO}$ nanoparticles and saccharides on biological responses," Int. J. Mol. Sci., vol. 19, no. 2, Feb. 2018.

27. S. Heena Khan, S. R, B. Pathak, and M. H. Fulekar, "Photocatalytic degradation of organophosphate pesticides (Chlorpyrifos) using synthesized zinc oxide nanoparticle by membrane filtration reactor under UV irradiation," Front. Nanosci. Nanotechnol., vol. 1, no. 1, pp. 23-27, 2015.

28. S. Yedurkar, C. Maurya, and P. Mahanwar, "Biosynthesis of Zinc Oxide Nanoparticles Using Ixora Coccinea Leaf Extract-A Green Approach," Open J. Synth. Theory Appl., vol. 05, no. 01, pp. 1-14, 2016.

29. C. Levard et al., "Sulfidation of Silver Nanoparticles: Natural Antidote to Their Toxicity," Environ. Sci. Technol., vol. 47, no. 23, pp. 13440-13448, Dec. 2013.

30. M. F. Z. R. Yahya, M. Y. Masod, and M. N. Zakaria (2013) ATRFTIR and UV/Vis spectrophotometric analyses of alpha-amylase bioactive paper," BEIAC 2013-2013 IEEE Bus. Eng. Ind. Appl. Colloq., pp. 240-245. 
31. Z. M. Milani, R. Jalal, and E. K. Goharshadi, "Carbodiimide for Covalent $\alpha$-Amylase Immobilization onto Magnetic Nanoparticles," Int. J. Nanosci., vol. 16, no. 5-6, Dec. 2017.

32. R. P. Dhavale et al., " $\alpha$-amylase immobilized on magnetic nanoparticles: Reusable robust nano-biocatalyst for starch hydrolysis," Mater. Res. Express, vol. 5, no. 7, p. 075403, Jul. 2018.

33. M. V. Kahraman, G. Bayramoğlu, N. Kayaman-Apohan, and A. Güngör, " $\alpha$-Amylase immobilization on functionalized glass beads by covalent attachment," Food Chem., vol. 104, no. 4, pp. 1385-1392, Jan. 2007.

34. M. Salgaonkar, S. S. Nadar, and V. K. Rathod, "Combi-metal organic framework (Combi-MOF) of $\alpha$-amylase and glucoamylase for one pot starch hydrolysis," Int. J. Biol. Macromol., vol. 113, pp. 464-475, Jul. 2018.

35. M. Azizi-Lalabadi, A. Ehsani, B. Divband, and M. AlizadehSani, "Antimicrobial activity of Titanium dioxide and Zinc oxide nanoparticles supported in $4 \mathrm{~A}$ zeolite and evaluation the morphological characteristic," Sci. Rep., vol. 9, no. 1, pp. 1-10, Dec. 2019.

36. R. Kumar, A. Umar, G. Kumar, and H. S. Nalwa, "Antimicrobial properties of $\mathrm{ZnO}$ nanomaterials: A review," Ceramics International, vol. 43, no. 5. Elsevier Ltd, pp. 3940-3961, 01-Apr-2017.

37. K. Date, in New Insights into Metabolic Syndrome (IntechOpen, 2020).

38. N. Antony, S. Balachandran, and P. V. Mohanan, "Immobilization of diastase $\alpha$-amylase on nano zinc oxide," Food Chem., vol. 211, pp. 624-630, Nov. 2016.

39. J. Cui, S. Ren, T. Lin, Y. Feng, and S. Jia, "Shielding effects of $\mathrm{Fe} 3+$-tannic acid nanocoatings for immobilized enzyme on magnetic Fe3O4@silica core shell nanosphere," Chem. Eng. J., vol. 343, pp. 629-637, Jul. 2018.

Publisher's Note Springer Nature remains neutral with regard to jurisdictional claims in published maps and institutional affiliations. 